Proc. Estonian Acad. Sci. Geol., 2001, 50, 2, 86-94

\title{
A NEW SUBSPECIES OF THE CLITAMBONITIDINE BRACHIOPOD ESTLANDIA CATELLATUS FROM THE MIDDLE ORDOVICIAN OF OSMUSSAAR ISLAND, ESTONIA
}

\author{
Olev VINN \\ Institute of Geology, University of Tartu, Vanemuise 46, 51014 Tartu, Estonia; vinn@ut.ee \\ Received 6 April 2000, in revised form 3 November 2000 \\ Abstract. A new subspecies Estlandia catellatus odini is described from the Uhaku Stage of \\ Osmussaar Island in Estonia. The unusual co-occurrence of three representatives of the genus \\ Estlandia (E. marginata (Pahlen), E. pyron pyron (Eichwald), and E. catellatus odini subsp. nov.) \\ in one bed in Osmussaar Island may have resulted from their partial post-mortem concentration \\ from different habitats.
}

Key words: Brachiopoda, Gonambonitidae, Estlandia catellatus odini subsp. nov., Ordovician, Llanvirn, Estonia.

\section{INTRODUCTION}

Öpik (1934) established the species Progonambonites? catellatus on the basis of a single ventral valve from Duboviki in Russia, dating it as Kunda age. Recently, numerous specimens of this species were collected from the Uhaku Stage in Osmussaar Island (Fig. 1). Based on the data obtained P. catellatus is assigned to the genus Estlandia. Two fossiliferous horizons $(1.20$ and $3.80 \mathrm{~m}$ above the lower boundary of the Lasnamägi Stage) have been previously recorded within the Väo Formation in the uppermost part of the Osmussaar cliff (Suuroja et al. 1999). The new material comes mostly from the $5-10 \mathrm{~cm}$ thick upper fossiliferous horizon (Fig. 2), exposed on the north coast of the island near the lighthouse and containing large numbers of various trilobites, gastropods, bivalves, and brachiopods. Three representatives of the genus Estlandia E. pyron pyron (Eichwald) (ten specimens; Pl. I, figs. 17, 18), E. marginata (Pahlen) (three specimens; Pl. I, figs. 19, 20; Fig. 3a), and a new subspecies E. catellatus odini (see below) - as well as the clitambonitids Clitambonites 


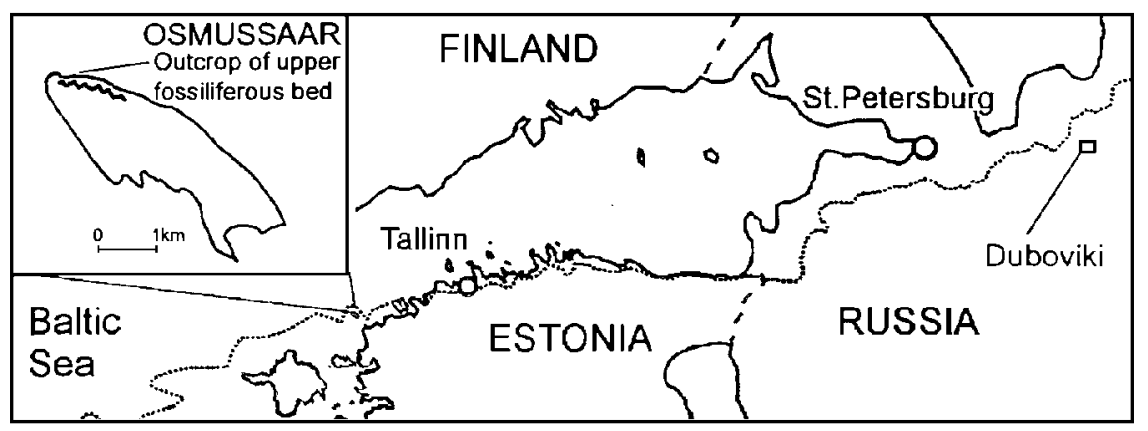

Fig. 1. Location of the Osmussaar (Estonia) and Duboviki (Russia) sections. Dotted line - BalticLadoga Klint.

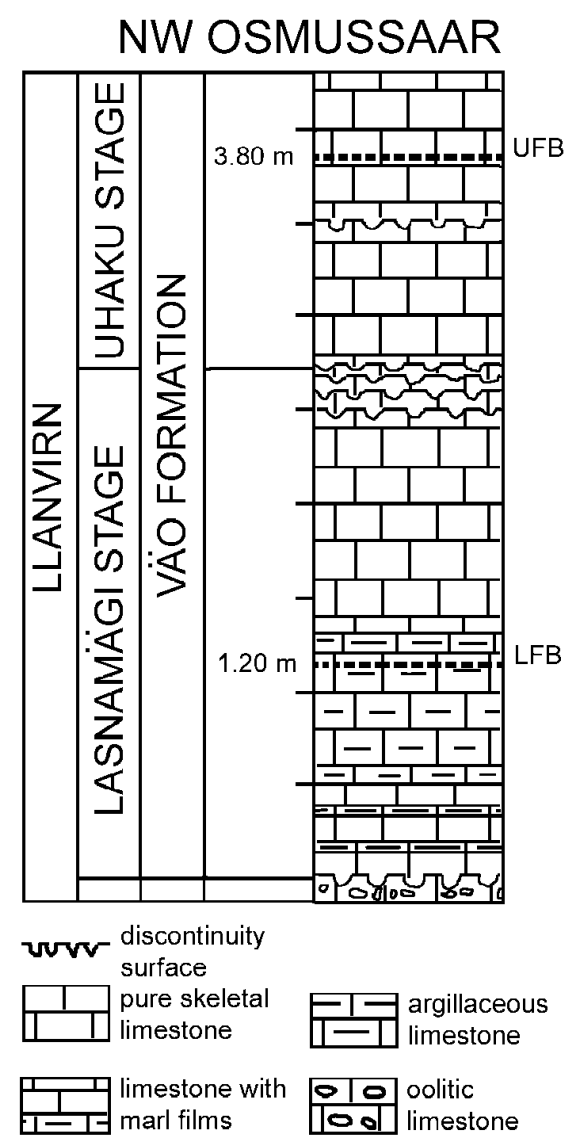

Fig. 2. The Osmussaar section near the lighthouse on the north coast of the island. UFB - upper fossiliferous bed; LFB - lower fossiliferous bed. Stratigraphy follows here Suuroja et al. (1999). 


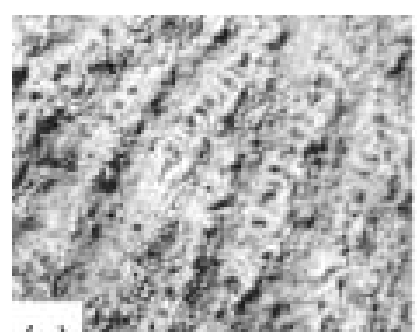

(a)
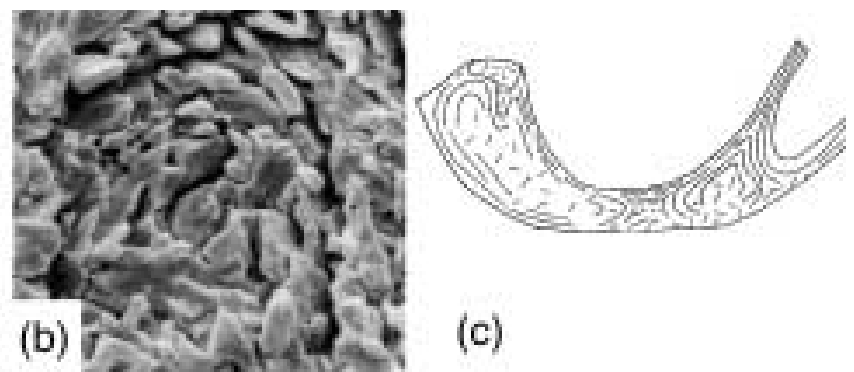

(c)

Fig. 3. (a) Estlandia marginata (Pahlen), TUG72-209, Uhaku Stage, Osmussaar Island, NW Estonia, spines on the dorsal valve, $\times 7.0$; (b), (c) E. catellatus odini subsp. nov., TUG1073-3, Uhaku Stage, Osmussaar Island, NW Estonia: (b) fibrous secondary layer with a pseudopuncta, $\times 3000$; (c) subperpendicular cross section of the ventral valve, showing different growth stages of spondylium triplex (see Vinn \& Rubel 2000, p. 443, fig. 3) - immature stage (left side of the figure) and adult stage (right side of the figure), $\times 10$.

schmidti (Pahlen), C. squamatus (Pahlen), and Vellamo simplex Öpik have been identified from there.

The shells of Estlandia pyron pyron from Osmussaar are somewhat smaller compared with those from the stratigraphically younger Kukruse Stage (Öpik 1930, pl. XX, figs. 243-247; pl. XXII, fig. 278; text-fig. 26). Yet, as no other differences are observed in the morphology of these specimens, they are considered con-subspecific. Most clitambonitidine valves are disarticulated (96\% of the 28 valves studied). Clitambonitidines as well as other groups of fossils are presumably not buried in situ, and such peculiar taphocoenoses may have formed as a result of the concentration of shells from different habitats by hydrodynamic activity.

The presence of Estlandia catellatus odini subsp. nov. in limestones as high as the lowermost Uhaku Stage is surprising in view of Öpik's original record of E. catellatus catellatus from the Kunda Stage at Duboviki, Russia, i.e. three stages lower. But, as Duboviki quarry is situated on the exposure of the Aseri, Lasnamägi, and Uhaku stages (Männil 1963), a younger age for E. catellatus catellatus seems more realistic than the Kunda one assumed by Öpik (1934).

In Estonia the occurrence of E. catellatus odini subsp. nov. is quite restricted. It has been recorded only from Osmussaar Island.

\section{SYSTEMATIC DESCRIPTIONS}

Repositories. All specimens are housed in the collections of the Museum of Geology, University of Tartu, and have been assigned TUG numbers.

Abbreviations used in the text. $\mathrm{L}=$ maximum length, $\mathrm{W}=$ maximum width, $\mathrm{T}=$ thickness of shell. All measures are in millimetres. 
Suborder CLITAMBONITIDINA Öpik, 1934

Superfamily CLITAMBONITOIDEA Winchell \& Schuchert, 1893

Family GONAMBONITIDAE Schuchert \& Cooper, 1931

Genus Estlandia Schuchert \& Cooper, 1931

Plate I; Figure 3

Type species. Estlandia marginata (Pahlen, 1877).

Species assigned. E. pyron pyron Eichwald, 1840; E. pyron silicificata Öpik, 1934; E. seidlitzi Rubel, 1963; E. catellatus catellatus Öpik, 1934; E. catellatus odini subsp. nov.

Estlandia catellatus odini subsp. nov.

Plate I, figures 4, 5, 7, 8, 10-14, 16; Figure 3b,c

Etymology. After the Swedish name (Odinsholm) of Osmussaar Island.

Holotype. Ventral valve TUG1073-1, Uhaku Stage, Osmussaar Island, Estonia.

Material and dimensions. One shell (TUG1073-5, $\mathrm{L}=12.0, \mathrm{~T}=5.2, \mathrm{~W}=13.2$ ), seven ventral valves (TUG1073-1, $\mathrm{L}=16.5, \mathrm{~W}=20.2$; TUG1073-2, $\mathrm{L}=13.6$, $\mathrm{W}=18.5$; TUG1073-3; TUG1073-10, $\mathrm{L}=13.9$, $\mathrm{W}=18.4$; TUG1073-7, $\mathrm{L}=-$, $\mathrm{W}=16.3$; TUG1073-8; TUG1073-9, $\mathrm{L}=14.6, \mathrm{~W}=21.7$ ), one ventral interior (TUG1073-6, $\mathrm{L}=-, \mathrm{W}=21.4$ ), five dorsal valves (TUG72-210, $\mathrm{L}=-, \mathrm{W}=20.6$; TUG1073-4, L=17.4, W=19.6; TUG46-125, L=16.0, W=20.0; TUG46-122, $\mathrm{L}=13.5, \mathrm{~W}=17.0 ; \quad \mathrm{TUG} 46-121, \mathrm{~L}=16.0, \mathrm{~W}=21.1$ ), one dorsal interior (TUG1073-11).

Locality and distribution. Osmussaar Island, NW Estonia, cliff on the north coast near the lighthouse, Väo Formation, lower part of the Uhaku Stage, Middle Ordovician.

Description. Shell biconvex, semielliptical in outline, $67-76 \%$ as wide as long, with the maximum width at the hingeline, maximum height at the hingeline. Anterior commissure rectimarginate, anterior margin slightly convex. Cardinal extremities obtuse to fairly acute, posterolateral sides straight.

Radial ornamentation finely multicostellate. Concentric fila, forming evenly spaced, individual short tubulous spines of regular shape, well developed all over the shell, with almost always perpendicular apices to the surface. The roundshaped spines are $0.1-0.4 \mathrm{~mm}$ wide, increasing slightly in size towards the anterior commissure. The spines may be elongated in the anterior region of the shell.

Ventral valve moderately convex, nearly flat in lateral profile, with the maximum height at the hingeline. Ventral interarea of moderate length, apsacline and flat. Delthyrium covered by deltidium. Foramen very minute, sealed and situated in the topmost part of deltidium. 

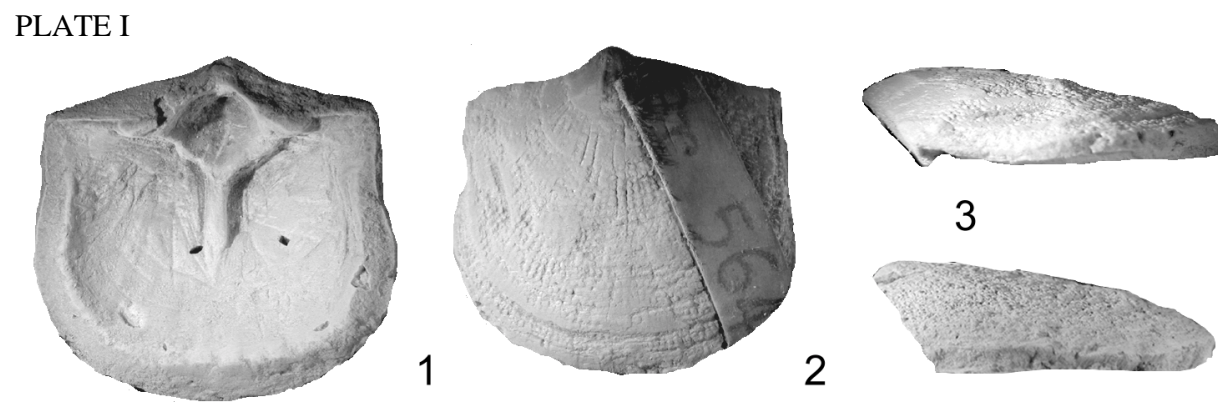

3
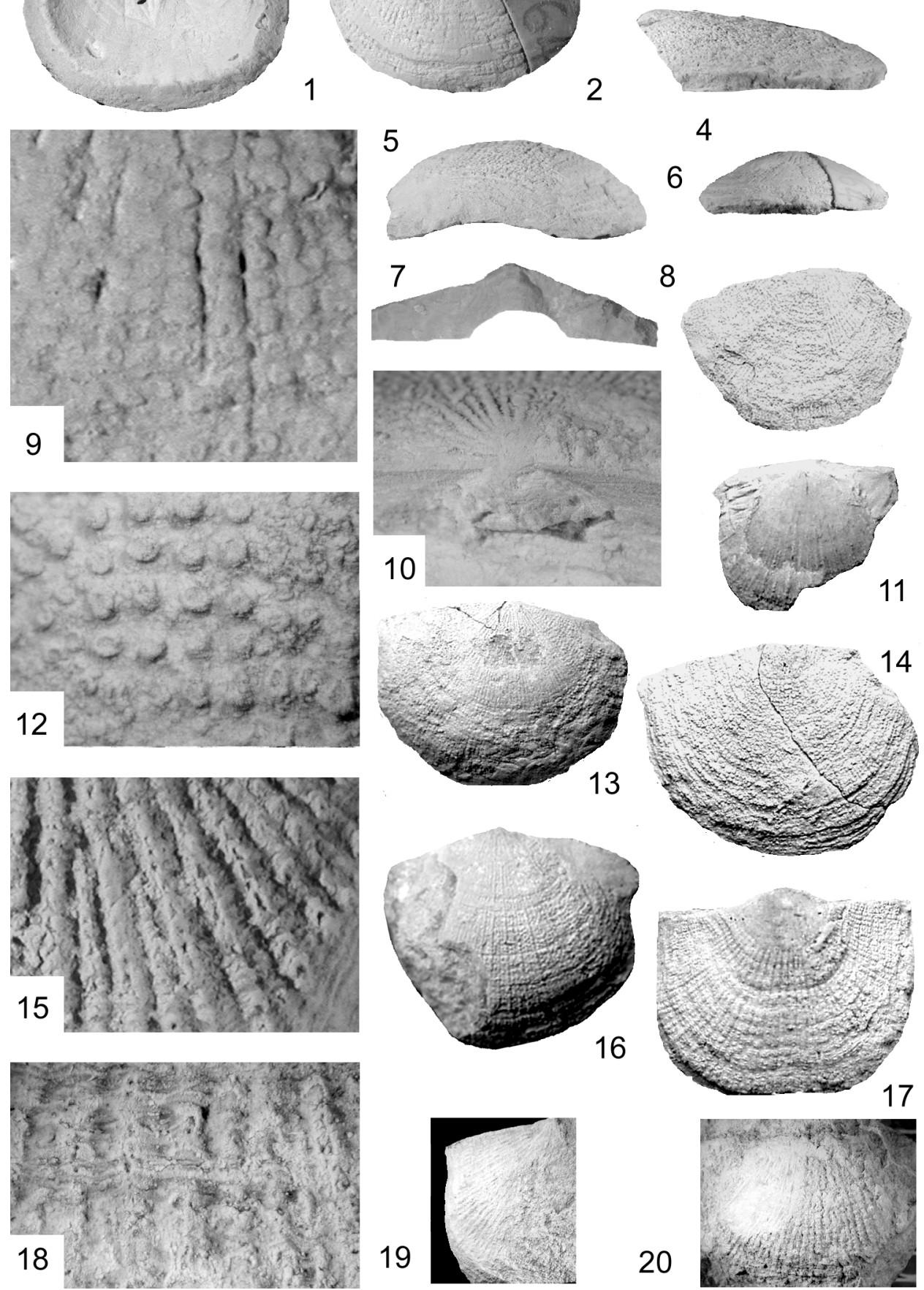
Ventral interior with the spondylium triplex, the well developed subspondylial lateral septa reaching the valve floor (Fig. 3c). Median septum prominent, extending up to midhalf of the valve length. Ventral subperipheral rim prominent.

Dorsal valve convex, strongly curved in lateral profile, with the maximum height at the midlength of valve. Dorsal interarea flat, apsacline, $1.7-2.0 \mathrm{~mm}$ long, about two times shorter than ventral interarea. Notothyrium completely covered by well developed chilidium.

Adductor scars developed as fair tracks on the valve floor, not elevated anteriorly. Dorsal anterior adductor scars slender and slightly longer than the posterior pair but the posterior pair is clearly wider. Adductor field about as long as the median ridge. Median ridge short and low, reaching about $1 / 3$ of valve umbo length.

Cardinal process simple, ridge-like, fused with the chilidium. Subperipheral rim prominent. Shell substance fibrous and pseudopunctate (Fig. 3b).

\section{Explanation of Plate I}

Figs. 1-3. Estlandia catellatus catellatus (Öpik), TUG1068-6, holotype, Uhaku Stage ?, Duboviki quarry, Russia: 1 , ventral valve interior, $\times 2.4 ; 2$, ventral valve exterior, $\times 2.2 ; 3$, ventral valve, lateral view, $\times 2.4$.

Figs. 4, 5. E. catellatus odini subsp. nov., Uhaku Stage, Osmussaar Island, NW Estonia: 4, TUG1073-1, holotype, ventral valve, lateral view, $\times 2.2 ; 5$, TUG1073-4, dorsal valve, lateral view, $\times 2.2$.

Fig. 6. E. catellatus catellatus (Öpik), TUG1068-6, holotype, Aseri Stage ?, Duboviki quarry, Russia, ventral valve, anterior view, $\times 1.7$.

Figs. 7, 8. E. catellatus odini subsp. nov., Uhaku Stage, Osmussaar Island, NW Estonia: 7, TUG1073-7, ventral interarea and deltidium, $\times 2.5 ; 8$, TUG1073-3, ventral valve exterior, $\times 2.2$.

Fig. 9. E. catellatus catellatus (Öpik), TUG1068-6, holotype, Aseri Stage ?, Duboviki quarry, Russia, spines on the ventral valve, $\times 10$.

Figs. 10-14. E. catellatus odini subsp. nov., Uhaku Stage, Osmussaar Island, NW Estonia: 10 , TUG72-210, umbonal view of the dorsal valve, $\times 7.5 ; 11$, TUG1073-5, mould of dorsal valve interior, $\times 2.0 ; 12$, TUG1073-1, holotype, spines on the ventral valve, $\times 12 ; 13$, TUG46-125, dorsal valve exterior, $\times 1.8$; 14, TUG1073-1, holotype, TUG1073-1, ventral valve exterior, $\times 2.0$.

Fig. 15. E. marginata (Pahlen), TUG1073-20, Kiviõli, Kukruse Stage, NE Estonia, spines on the dorsal valve, $\times 7.0$.

Fig. 16. E. catellatus odini subsp. nov., TUG1073-4, dorsal valve exterior, $\times 2.2$.

Figs. 17, 18. E. pyron pyron (Eichwald), TUG72-208, Uhaku Stage, Osmussaar Island, NW Estonia: 17 , ventral valve exterior, $\times 1.8 ; 18$, poorly developed rare spines on the ventral valve, $\times 8.0$.

Figs. 19, 20. E. marginata (Pahlen), TUG72-209, Uhaku Stage, Osmussaar Island, NW Estonia: 19 , ventral valve exterior, $\times 1.2 ; 20$, dorsal valve exterior, $\times 1.2$. 
Discussion. E. catellatus is assigned here to the genus Estlandia because of its typical of that genus ornamentation. The species has also a well developed complete chilidium, median septa in both valves (see Alikhova 1953, p.98; Rubel 1963, p. 106), and delthyrium covered by deltidium, all characteristic of the genus. The nominal subspecies E. catellatus catellatus (Pl. I, figs. 1-3, 6, 9; see also Öpik 1934, pp. 141-142, pl. XXIV, figs. 4, 5; text-fig. 6F) has shell length larger than width ( $105 \%$ as wide as long, $\mathrm{L}=15.8, \mathrm{~W}=15.0$ in holotype TUG1068-3), and the maximum width at $1 / 3$ of the length from the anterior margin, unlike the specimens of E. catellatus odini subsp. nov., which have much wider shells (67-76\% as wide as long), and the maximum width of shell always at the hingeline (Fig. 4). E. catellatus resembles most of all E. marginata in outline (see Öpik 1930, pl. XIX, figs. 229-236, fig. 248; pl. XX, figs. 236239 , text-figs. 24,25$)$ : both have transverse outline, rectimarginate anterior commissure, and equal size of shell. E. catellatus has finer and smoother radial ornamentation than E. marginata, but also well developed and clearly finer spines $(0.1-0.4 \mathrm{~mm}$ in E. catellatus versus $0.4-1.0 \mathrm{~mm}$ in E. marginata), which are evenly spread all over the shell surface and have more regular shape. E. marginata has coarser and less developed spines which occur only in the middle and anterior regions of both valves. The spines in E. marginata are usually joined, placed side by side along the costellae (Pl. I, fig. 15; Fig. 3a), while those in E. catellatus are almost always single.

Three types of spines at different stages of development can be distinguished in Estlandia. This lineage begins with E. seidlitzi (Rubel 1963, p. 104, pl. III, figs. 2, 5, 6) and E. pyron pyron which have few and weakly developed spines (Pl. I, fig. 18), if at all; the intermediate E. marginata has more or less developed spines which are mostly joined along the distal part of the costella (Pl. I, fig. 15; Fig. 3a) and, finally, E. catellatus has well developed and individual spines all over the shell (Pl. I, figs. 9, 12). E. catellatus (Öpik) has less acute cardinal extremities than E. marginata; the latter has a faint sulcus on the dorsal valve,

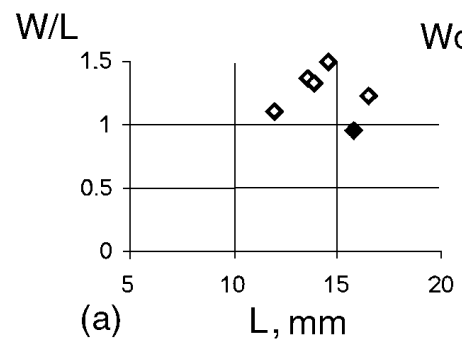

Wd/Lhl

Fig. 4. (a) Width/length (W/L) ratio of the ventral valves. Solid square - Estlandia catellatus catellatus (Öpik), blank squares - E. catellatus odini subsp. nov. (b) Ratio of the width of the dorsal valve $(\mathrm{Wd})$ to the length of the hingeline (Lhl). Solid squares - E. catellatus odini subsp. nov., blank square - E. catellatus catellatus (Öpik). 
which is missing in the first species. E. catellatus has a radial ornamentation resembling that of E. pyron (Öpik 1930, pl. XX, figs. 243-247; pl. XXII, fig. 278; text-fig. 26), but E. catellatus differs from E. pyron in the lack of the dorsal sulcus, a smaller size and more regular shape of spines, greater number of spines and their presence in the umbonal region of the shell. E. pyron has clearly uniplicate anterior commissure, while the commissure in E. catellatus is rectimarginate.

\section{ACKNOWLEDGEMENTS}

I am grateful to L. Hints, M. Rubel, T. Pani, and I. Puura for helpful comments on the manuscript. Financial support through a $\mathrm{PhD}$ research grant (DBGGL 0755) from the University of Tartu and grant No. 3274 of the Estonian Science Foundation is acknowledged.

\section{REFERENCES}

Alikhova, T. 1953. Rukovodyashchaya fauna brakhiopod ordovikskikh otlozhenij severo-zapadnoj chasti Russkoj platformy. Gos. izd-vo geol. lit., Moskva (in Russian).

Männil, R. 1963. On the correlation of the Ordovician strata of Estonia and Leningrad Region. ENSV TA Geol. Inst. Uurimused, 13, 11-12 (in Russian).

Öpik, A. 1930. Brachiopoda Protremata der Estländischen Kukruse-Stufe. Acta Comment. Univ. Tartuensis, 17.

Öpik, A. 1934. Über Klitamboniten. Acta Comment. Univ. Tartuensis, 26.

Rubel, M. 1963. On Baltic Lower Ordovician Gonambonitids (Clitambonitacea, Brach.). ENSV TA Geol. Inst. Uurimused, 13, 91-107 (in Russian).

Schuchert, C. \& Cooper, G. A. 1931. Synopsis of the brachiopod genera of the suborder Orthoidea. Am. J. Sci., 22.

Suuroja, K., Saadre, T. \& Kask, J. 1999. Geology of Osmussaar Island. Estonia Maritima, 4, 39-63.

Vinn, O. \& Rubel, M. 2000. The spondylium and related structures in the clitambonitidine brachiopods. J. Paleontol., 74, 439-444.

Winchell, N. H. \& Schuchert, Ch. 1893. The lower Silurian Brachiopoda of Minnesota. In The Geology of Minnesota, Vol. 3 (1) (Lesquereux, L., Woodward, A., Thomas, B. W., Schuchert, Ch., Ulrich, E. O. \& Winchell, N. H., eds.), pp. 333-474. Geological and Natural History Survey of Minnesota, Final Report. Harrison \& Smith, Minneapolis.

\section{KESKORDOVIITSIUMI KLITAMBONITIIDSE KÄSIJALGSE ESTLANDIA CATELLATUS UUS ALAMLIIK OSMUSSAARELT}

\section{Olev VINN}

Osmussaarelt pärineva materjali põhjal on Progonambonites? catellatus Öpik arvatud perekonda Estlandia kuuluvaks. Esmakordselt on kirjeldatud selle liigi 
dorsaalkaant ja uut alamliiki E. catellatus odini. Uhaku-vanuse Osmussaare materjali olemasolu lubab kahelda Venemaalt Dubovikist pärineva holotüübi Kunda vanuses, tõenäoliselt pärineb holotüüp siiski noorematest kihtidest. Perekonna Estlandia kolme esindaja E. pyron pyron (Eichwald), E. marginata (Pahlen) ja E. catellatus odini subsp. nov. koosesinemine Osmussaarel ühes kihis on osaliselt seletatav eri biotoopidest kokkukantud materjaliga.

\section{НОВЫЙ ПОДВИД КЛИТАМБОНИТИДНОЙ БРАХИОПОДЫ ESTLANDIA CATELLATUS ИЗ СРЕДНЕГО ОРДОВИКА ОСТРОВА ОСМУССААР, ЭСТОНИЯ}

\section{Олев ВИНН}

\footnotetext{
Новый материал с о-ва Осмуссаар показывает, что Progonambonites? catellatus Öpik принадлежит к роду Estlandia. Описан новый его подвид Estlandia catellatus odini subsp. nov. Осмуссаареский материал обнаружен в нижней части ухакуского горизонта. Три представителя рода Estlandia E. pyron pyron (Eichwald), E. marginata (Pahlen) и E. catellatus odini subsp. nov. - найдены в одном слое.
} 